NBER WORKING PAPER SERIES

\title{
TRAINING DISADVANTAGED YOUTH IN LATIN AMERICA: EVIDENCE FROM A RANDOMIZED TRIAL
}

\author{
Orazio Attanasio \\ Adriana Kugler \\ Costas Meghir \\ Working Paper 13931 \\ http://www.nber.org/papers/w13931 \\ NATIONAL BUREAU OF ECONOMIC RESEARCH \\ 1050 Massachusetts Avenue \\ Cambridge, MA 02138 \\ April 2008
}

We are extremely grateful to the teams at SEI and Econometria, which participated in the coordination and collection of the data, and in particular to Rafael Arenas, Luis Carlos Gomez, John Tirado and especially to the director of the project, Bernardo Kugler, and to the deputy director, Martha Isabel Gutierrez, for making sure the process was carried out in a careful manner every step of the way. We are also very grateful to Luis Carlos Corral at the Department of Planning for hearing our plea and supporting us in carrying out the randomization. We thank Josh Angrist, Jere Behrman, Bill Evans, David Francis, Jim Heckman, and Jesse Rothstein for very helpful comments, as well as to seminar participants at the World Bank, the University of Notre Dame, the IZA/World Bank Employment and Development Conference and at the TIMES seminar at the University of Houston. Adriana Kugler gratefully acknowledges financial support from a University of Houston GEAR grant. Orazio Attanasio and Costas Meghir's research have been financed by an ESRC professorial fellowship and the ESRC centre at the IFS. The views expressed herein are those of the author(s) and do not necessarily reflect the views of the National Bureau of Economic Research.

NBER working papers are circulated for discussion and comment purposes. They have not been peerreviewed or been subject to the review by the NBER Board of Directors that accompanies official NBER publications.

(C) 2008 by Orazio Attanasio, Adriana Kugler, and Costas Meghir. All rights reserved. Short sections of text, not to exceed two paragraphs, may be quoted without explicit permission provided that full credit, including $\odot$ notice, is given to the source. 
Training Disadvantaged Youth in Latin America: Evidence from a Randomized Trial

Orazio Attanasio, Adriana Kugler, and Costas Meghir

NBER Working Paper No. 13931

April 2008

JEL No. C21,I38,J24

\begin{abstract}
$\underline{\text { ABSTRACT }}$
Youth unemployment in Latin America is exceptionally high, as much as 50\% among the poor. Vocational training may be the best chance to help unemployed young people at the bottom of the income distribution. This paper evaluates the impact of a randomized training program for disadvantaged youth introduced in Colombia in 2005 on the employment and earnings of trainees. This is one of a couple of randomized training trials conducted in developing countries and, thus, offers a unique opportunity to examine the causal impact of training in a developing country context. We use originally collected data on individuals randomly offered and not offered training. We find that the program raises earnings and employment for both men and women, with larger effects on women. Women offered training earn about $18 \%$ more than those not offered training, while men offered training earn about $8 \%$ more than men not offered training. Much of the earnings increases for both men and women are related to increased employment in formal sector jobs following training. The benefits of training are greater when individuals spend more time doing on-the-job training, while hours of training in the classroom have no impact on the returns to training. Cost-benefit analysis of these results suggests that the program generates a large net gain, especially for women.
\end{abstract}

Orazio Attanasio

Department of Economics

University College London

Gower Street

London WC1E 6BT UNITED KINGDOM

and NBER

o.attanasio@ucl.ac.uk

Adriana Kugler

University of Houston

Department of Economics

204 McElhinney Hall

Houston, TX 77204-5019

and NBER

adkugler@uh.edu
Costas Meghir

Department of Economics

University College London

Gower Street

London WC1E 6BT ENGLAND

c.meghir@ucl.ac.uk 


\section{Introduction}

Youth unemployment is exceptionally high in Latin America, to the point that it triples the unemployment rate of adults in the region. Youth unemployment is even more of a problem among those at the lower end of the income distribution. In the late 1990s, the youth unemployment rate in the first income quartile was 13 times higher than the youth unemployment rate in the fourth quartile in Honduras, 9 times higher in Argentina, 8 times higher in Bolivia, 5 times higher in Chile and 2 times higher in Colombia and Panama. ${ }^{1}$ This is a sad start to the beginning of anyone's labor market experience and likely affects adult employment prospects. At the same time, these high youth unemployment rates, especially among the poor, raise concerns about young people engaging in criminal activities given the lack of better prospects. In fact, violent activity among young people has contributed to the steep rise in urban violence during the 1990s in Latin America, with Colombia, Brazil, Mexico and Venezuela heading the list. In addition to the usual concerns about youth unemployment in terms of poor future labor market prospects and increased crime, there is the concern that living standards may be affected substantially by youth unemployment in Latin America, where young people, and even children, are substantial contributors to household income.

Lack of skills is thought to be one of the key determinants of major social problems such as youth unemployment, poverty and crime as well as a key limitation to growth in developing countries. Education programs have, thus, been at the heart of developing policies and have been backed up by Conditional Cash Transfers such as the Progresa/Oportunidades program in Mexico and the Familias en Acción program in Colombia among many others.

\footnotetext{
${ }^{1}$ See Hopenhayn (2002).
} 
However, by their nature these interventions take a long time to translate into poverty reduction and require further investments in quality improvements. Given the urgency of this matter the question is whether it is possible to intervene and improve the outcomes for young adults. If so what form should such an intervention take?

While early interventions and improvements in the quality of education at all levels may be key for long-term poverty alleviation (see Carneiro and Heckman, 2003), these interventions may reach young people too late - either close to the end of their schooling or in their early post-schooling years. Vocational training may thus be the best chance to improve the labor market prospects of youth at the bottom of the income distribution and may also help avoid the rise of social problems such as crime and extreme poverty that result from youth unemployment. However, while there may be good reasons to advocate the use of training programs in developing countries, there is little reliable evidence on the impact of training on improving the labor market standing of the poor. Indeed, mixed results on the impact of government training programs in the US, the UK and other industrialized countries justifies some a priori skepticism as to whether such interventions can deliver positive and cost-effective results, helping poverty alleviation. ${ }^{2}$

The picture, however, could be different in developing countries, as one may expect the returns to training to be higher where the levels of skills of the population are very low to begin with. A number of training programs for disadvantaged workers have been introduced in recent years in many countries, including Argentina, Brazil, Chile,

\footnotetext{
${ }^{2}$ See LaLonde (1995) and Heckman, LaLonde and Smith (1999) for surveys of the literature and Carneiro and Heckman (2003) and Heckman and Krueger (2003) for a general discussion of human capital policies. Also, see LaLonde (1986), Card and Sullivan (1988) and Burghardt and Schochet (2001) for some selected studies of randomized training programs in the U.S.
} 
Colombia, the Dominican Republic, Panama, Peru and Uruguay, and indeed suggest positive returns in Latin America especially for women. ${ }^{3}$ However, these programs have largely been evaluated using non-experimental technique making it difficult to disentangle the causal effect of training from selection of program participants. ${ }^{4}$

An intervention in Colombia, combined with a randomized experiment, gives us an almost unique opportunity to offer reliable evidence on the value of training in developing countries. The program "Jóvenes en Acción" (which translates as Youth in Action) was introduced between 2001 and 2005 and provided 3 months of in-classroom training and 3 months of on-the-job training to young people between the ages of 18 and 25 in the two lowest socio-economic strata of the population. Training institutions in the seven largest cities of the country chose the courses to be taught as part of the program and received applications. Each institution was then asked to select more individuals than they had capacity for. Subsequently, the program randomly offered training to as many people as there were slots, among the individuals initially chosen by the training institutions. The remaining youths were then used as a control group not selected into training. ${ }^{5}$ The advantage of this design is that it attempts to capture the process of trainee selection as it would take place in practice, rather than force the training institutions to train individuals they would otherwise not choose to train.

Results on the impacts of the program show large effects. Comparisons between those offered and not offered training show that both women and men offered training do

\footnotetext{
${ }^{3}$ See Betcherman, Olivas and Amit Dar (2004), Elias et al. (2004) and Card et al. (2007).

${ }^{4}$ The study by Card et al. (2007) on the Dominican Republic is the only other randomized evaluation of a training program in a developing country. Their estimates are positive but not significant, at conventional significance levels. We discuss this study below.

${ }^{5}$ In practice, some training centers did not receive enough qualified applicants to select the extra $50 \%$ initially requested. For this reason, the probability of being offered training actually varies by training institution.
} 
better in the labor market. The comparisons between individuals offered and not offered training are known as intention-to-treat (ITT) effects. In the case of "Jóvenes en Acción," the intention-to-treat effects are likely to be very close to the average effects of training because there is close to full compliance. In particular, the probability of receiving training is about 0.96 higher for those who were initially offered training relative to those who were not. Few individuals who are not initially offered a slot in a course are eventually trained, and even fewer of those individuals who were offered a slot turn down the opportunity to train.

Intention-to-treat effects show that women offered training are more likely to be employed and work more days and longer hours. In particular, being offered training increases paid employment by about $14 \%$ and increases days and hours worked by about $11 \%$. The monthly wage and salary earnings of women offered training are about 30,000 Colombian pesos (US\$15) or 18\% higher than those of women not offered training. Moreover, the likelihood of being employed in jobs that offer non-wage benefits and of having a written contract is 0.05 higher for women offered training. In fact, the gains from training seem largely linked to employment in the formal sector, as wage and salary earnings gains after training are only linked to those in the formal sector but not for informal sector workers. Men also benefit from being offered training, but the effects for men are more limited. The monthly wage and salary earnings of men offered training are 22,600 Colombian pesos or $8 \%$ higher than the salaries of those not offered training. Training offers also double the likelihood of getting a formal sector job and a job with a written contract for men. Also, as for women, wage and salary earnings gains after training are due to earnings increases for those employed in the formal sector. On the 
other hand, women and men offered training had shorter tenures by about 1 and a half and 3 months, respectively, compared to those who were not trained, possibly because of the automatic withdrawal from the labor force during the three months of classroom training. Nonetheless, this decreased tenure should be considered as a cost of the program.

An interesting finding is that training has stronger effects on earnings and employment, the greater the intensity of on-the-job training. By contrast, the returns to training are not related to hours of classroom training, nor were they related to whether training was provided by a for-profit or non-profit training institution. The strong effects of the on-the-job component of training, together with the importance in terms of placing workers in formal sector jobs, suggests that the program may have played the role of a placement-like service or job-search assistance by providing information to both workers and employers. Of course, we should be cautious in interpreting these results because this duration was not randomly assigned and the effect could reflect the quality of the applicant, with better applicants getting longer internships or even permanent jobs after the program.

These results stand in strong contrast to most of the results obtained in developed countries and, in particular, in the U.S. (see, e.g., Heckman and Krueger, 2003; Burghardt and Schochet, 2001; Heckman, LaLonde and Smith, 1999). In these countries the effects are often small, if at all positive, and it is often unclear whether from they are worth implementing from a cost-benefit perspective. The picture, however, could be different in developing countries as one may expect the returns to be higher where the levels of skills of the population are very low to begin with. A number of training programs for 
disadvantaged and low skilled individuals have been introduced in recent years in many countries, including Argentina, Brazil, Chile, Colombia, Dominican Republic, Panama, Peru and Uruguay, and indeed suggest high returns. However, unlike in the Colombian program we study, in the majority of these programs individuals were not randomized into training. As a consequence, these studies have mostly been evaluated using nonexperimental techniques. Consistent with the results in this paper, for the most part, the results from these non-experimental analyses show positive effects on the earnings of women. An exception to these non-experimental evaluations in developing countries is the work by Card et al. (2007) for the Dominican Republic which finds positive, though insignificant, effects on earnings and on the probability of getting a job with health insurance of similar magnitudes we find here. The authors attribute the insignificant effects to their small sample sizes.

The rest of the paper proceeds as follows. Section 2 provides some background on the basic design and implementation of the program Jóvenes en Acción. Section 3 describes the experimental design, as well as the collection of the data. Section 4 provides descriptive statistics and comparisons between the treatment and control groups at baseline. Section 5 presents first-stage results on the impact of a training offer on actual training, and then presents estimates of the intention-to-treat effects of the program on labor market outcomes, controlling for training institution fixed effects and pre-treatment characteristics. Section 6 shows cost-benefit analyses for women and men and Section 7 concludes. 


\section{Background and Description of the Program}

In 1998 Colombia was hit by the strongest recession in almost 60 years. While the economy had an average GDP growth of 3\% for the entire decade of the 1990s, in 1999 Colombia's GDP growth fell to $-6.0 \%$. The economy only recovered to $3 \%$ GDP growth again in 2003.

Given the absence of safety nets in the Colombian economy and the devastating effect that the recession was having on the poorest segments of the population, in 2001 the Colombian government introduced three new social programs to help those hardest hit by the recession, ${ }^{6}$ which were financed with a loan from the World Bank and the Inter-American Development Bank. The three programs were "Familias en Acción," "Empleo en Acción," and "Jóvenes en Acción." The first was a conditional cash transfer program, similar to the Progresa program in Mexico, which provides stipends for rural families conditional on sending their children to school and providing health checks to the children. The second was a workfare-type program, similar to "Trabajar" in Argentina, which provided temporary government employment to low-income adults. The third, "Jóvenes en Acción," which is the program evaluated in this study, provided training to young people living in urban areas.

The program "Jóvenes en Acción" reached 80,000 young people (or approximately $50 \%$ of the target population) and was given to various cohorts over a period of four years. The first cohort received training in 2002 and the last one in 2005 . This analysis evaluates this last cohort.

\footnotetext{
${ }^{6}$ It is worth noting that unemployment insurance did not exist in Colombia until 2003 when it was introduced by legislation.
} 
The program was targeted to young people between the ages of 18 and 25 , who were unemployed and who were placed in the two lowest deciles of the income distribution. The program spent US\$70 million or US\$875 per person and was offered in the seven largest cities of the country: Barranquilla, Bogotá, Bucaramanga, Cali, Cartagena, Manizales and Medellin.

Training consisted of 3 months of classroom training and 3 months of on-the-job training. Classroom training was provided by private and public training institutions, which had to participate in a bidding process to be able to participate in the program. The training institutions were selected based on the following criteria: legal registration, economic solvency, quality of teaching, and ability to place trainees after the classroom phase into internships with registered employers. In 2005, there were a total of 118 training institutions offering 441 different types of courses to 989 classes with a total of 26,615 slots for trainees, which means that the average class had 27 students. Training courses provided vocational skills in a diverse number of occupations. ${ }^{7}$ It is important to stress that the private training institutions played a fundamental role in determining what courses were offered, how they were marketed and how they were designed. The maximum number of hours of lectures was set at 350 hours for three months (or about 6 hours of lectures during weekdays). Of the participating training institutions $43.2 \%$ were for profit and 56.8\% were non-profit. Training institutions were paid according to market prices and were paid conditional on completion of training by the participants of the program.

\footnotetext{
${ }^{7}$ Courses included training for: taxi and bus drivers; office assistants; call center operators; nurses' and physicians' assistants; pharmacy assistants; hairdressing and cosmetology assistants; inventory assistants; archival assistants; preschool teacher assistants; cashiers; payroll assistants; assistants for computer installation and maintenance; textile operators; woodcutting machine operators; carpentry assistants, plumber assistants, and electricians' assistants.
} 
On-the-job training was provided by legally registered companies, which provided unpaid internships to the participants. There were a total of 1,009 companies that participated in the program. These companies operated in manufacturing (textiles, food and beverages, pharmaceuticals, and electricity), retail and trade, and services (including security, transportation, restaurants, health, childcare, and recreation).

The program provided a stipend of about US $\$ 2.20$ per day to male and female trainees without young children throughout the 6 months in the program to cover for transportation and lunch. The amount was increased to about US\$3.00 per day for women with children under 7 years of age to help cover for childcare expenses.

\section{Experimental Design and Data Collection}

\subsection{Experimental Design}

As a rule the earnings of trainees and non-trainees are unlikely to be directly comparable for reasons that have been extensively discussed (see Heckman, LaLonde and Smith, 1999). Random assignment allows us to overcome selection bias in the evaluation of Youth in Action. The randomization worked as follows: each training institution provided a list of up to $50 \%$ more applicants than they had capacity for; then, these individuals were randomly offered or not offered a position in a course at each training institution using the special information system set up to register applicants into the program. Since the total number of slots per course was fixed but the number of people pre-selected in the training list varied by training institution, the probability of being offered a spot in a course also differed by training institution. ${ }^{8}$

\footnotetext{
${ }^{8}$ The median probability of being offered training was 0.815 and the average probability of being offered training was 0.85 with a standard deviation of 0.12 .
} 
If the individuals who were initially assigned to the program did not accept the training opportunity, then the training institutions were allowed to fill these slots with the next individual in the lists randomly generated by the information system. In addition, individuals who were not initially offered a slot could request to be released from the waiting list in a particular training institution and to apply to other institutions. In practice, there were only 56 individuals in our sample who did this. This means that although the trainees were randomly assigned for the most part, these 56 individuals (i.e., $1.29 \%$ of our sample) who initially did not get assigned to treatment but got trained and the 8 (i.e., $0.18 \%$ of our sample) who turned down training may be self-selected and introduce a bias. For this reason, our analysis is based on the initial random assignment. However, the number of non-compliers was so small that, in practice, it does not matter for the results we obtain.

An important advantage of this study is that the availability of training was randomly assigned among those who chose to apply for training and were selected as suitable by the training institutions. Because of the limited non-compliance we reported above, the direct comparison of outcomes between the group that was offered training and the group that was not will yield unbiased estimates of the average effect of offering training on those who apply for it and are accepted by one of the training institutions. Given the design of the program, we estimate the effect of an offer to train on the population of interest, namely those who would be accepted into the program by those delivering it. Moreover, by asking the training institutions to select more candidates than they had places, the experiment comes closer to identifying the effect following an 
overall expansion of the program to a population, which currently does not have full access. $^{9}$

\subsection{Data Collection}

Given the design of the randomization described above, the data set used for this evaluation, includes a treatment and a control group, in each of the seven cities covered by the program. There were two stages to the data collection: the first stage conducted a baseline survey which collected information on the individuals in the sample before their participation into the program, and a second stage which conducted a follow-up survey and collected information on individuals after the end of the two components of training (i.e., the classroom and on-the-job training).

Table 1 provides information on the size of the samples and reports the planned and actual number of interviews conducted at baseline and in the follow-up surveys by city. We chose the number of interviews to be able to detect effects similar to those found in other programs based on a $10 \%$ level of significance. This yielded a sample of 3,300 with 1,650 in each group. Taking an ex-ante pessimistic view on attrition, ${ }^{10}$ we increased the sample to 2,040 and 2,310 for the treatment and control groups, respectively.

The baseline sample includes 2,066 individuals in the treatment group and 2,287 controls. The sample was stratified by city and sex, with equal numbers of women and men in each city. This allows us to carry out separate analyses of the program for women and men, which as we will show in the next sections show different effects for the two genders.

\footnotetext{
${ }^{9}$ In Manizales and Cali, however, several training institutions did not get enough applicants to be able to select more individuals than they had capacity for.

${ }^{10}$ The expected attrition was $24 \%$ for the program participants and $40 \%$ for the non-program participants.
} 
The baseline data (before the provision of training) was collected in January 2005 either before the beginning of the training program or during the first week of classes to minimize any influence of participation in the program on the interviewees' responses. The follow-up interviews were carried out between August and October of 2006 or between 19 and 21 months after the beginning of the program (since the program started at the end of January 2005) with the idea of allowing at least one year since the completion of the program to evaluate its effectiveness in terms of labor market outcomes.

Since there were concerns with attrition, especially for a highly mobile group of young people in the lowest socio-economic strata of the population, telephone updates were conducted on November 2005 or 4 months after the completion of the program. These telephone follow-ups verified the basic personal information of the baseline interviewees and got up-to-date contact information, including addresses and telephone numbers, for those who had moved or were about to move. Telephone numbers were available for 4,298 of the 4,353 individuals initially interviewed at baseline, so that there were missing phone numbers only for 55 individuals or $2 \%$ of those initially interviewed. Of the ones with a phone number, 3,736 or $85.8 \%$ were reached. Of these 163 or $4.36 \%$ had moved and it was not possible to get new contact information. Out of the 617 who were not reached, $71 \%$ had their phone lines cut off or not working. However, personal visits were then conducted to update the information of these 617 individuals.

The complete follow-up in-person interviews were carried out between 9 and 11 months after the telephone update. The follow-up was conducted using the initial list of individuals in the baseline with the contact information updated by telephone in 
November. The last two columns in Table 1 present the number of actual interviews carried out during the follow-up. There were 1,749 and 1,814 treatment and control individuals interviewed in the follow-up approximately one year after the training program finished. This is $85 \%$ and $79 \%$ of the treatment and control groups relative to the samples in the baseline or $81.8 \%$ of the total initial sample. ${ }^{11}$ This low attrition rate is remarkable, especially considering that the data collection took place in a less developed country and for a sub-population which is highly mobile. More importantly, attrition is unrelated to random training offers for both women and men. ${ }^{12}$

\section{Data Description and Baseline Comparisons}

\subsection{Descriptive Statistics}

The baseline and follow-up surveys collected information for all individuals drawn both from the treatment and control populations and included three parts. The first part of the survey collected information on the demographic characteristics of all treatment and control individuals and those living in the same households. The second part included questions on education, training, health and general labor market information for all individuals older than 12 years of age living in the households of the treatment and control individuals. The third and most pertinent part of the survey included detailed questions to the treatment and control individuals on their labor market experience during the year prior to the survey. In addition, during the follow-up,

\footnotetext{
${ }^{11}$ This attrition rate compares very favorably to the attrition rates found in labor market surveys for developed countries (e.g., the attrition rate for the CPS is around 20\%).

${ }^{12}$ The coefficients on a random offer dummy in linear probability models of the probability of continuing in the sample are -0.0012 with a se of 0.0034 for women and -0.0009 with a se of 0.0028 for men.
} 
questions were asked to those who participated in the program (treatment group) about their training experience.

Table 2 reports basic descriptive statistics on the pre-treatment and post-treatment demographic characteristics and labor market outcomes of women and men in the treatment and control groups. ${ }^{13}$ The labor market variables include employment status, hours, days, earnings and the quality of jobs. We distinguish between employment and paid employment. We also distinguish between earnings from wage and salary employment and earnings from self-employment. Our earnings, tenure, days, and hours measures all include zeros for those not working. ${ }^{14}$ Two interesting outcomes that we consider in our analysis are whether the worker is employed in a formal sector job or not and whether she has a contract. These two measures are indicator variables which take the value of one if an individual is employed in the formal sector and has a written contract and zero if she is not working at all or works in the informal sector or without a written contract. This distinction between the formal and informal sector is important in developing countries where being in the formal sector implies access to pensions, health and other benefits as well as better working conditions. The Appendix includes a detailed description of how the various variables were constructed.

The average age of women and men in the sample before training was 21 years of age. About a quarter of the women and $10 \%$ of the men in the sample were married before the program. Educational attainment was low with both women and men having about 10 years of education and, thus, being high school dropouts. Employment during

\footnotetext{
${ }^{13}$ The smaller number of observations reported for the follow up sample reflects attrition. However, as pointed out, attrition is not related to the probability of receiving a random offer, so that it is unlikely to introduce biases.

${ }^{14}$ Below we discuss the implications of including zeros in our earnings and other measures for the interpretation of our results.
} 
the year before training is low for both groups in terms of participation (i.e., 0.34 for women and 0.4 for men), in terms of days worked per month (i.e., 11 for women and 14 for men), and in terms of hours worked per week ( 23 for women and 30 for men). The probability of having had a formal sector job during the past year, which includes coverage for pensions, health insurance and/or injury compensation is only 0.07 for women and 0.12 for men. The probability of having had a job with a written contract is equally low. Moreover, wage and salary earnings and self-employment earnings are also low for both women and men. Women's monthly wage and salary earnings are 86,716 Colombian pesos or US $\$ 42.14$ per month or US\$1.4 per day, and men's monthly wage and salary earnings are 124,647 Colombian pesos or US $\$ 60.57$ per month or US\$2.02 per day. If these individual earnings were the only source of income in their households, then these individuals would be living in poverty or close to extreme poverty. ${ }^{15}$ Selfemployment earnings are even lower.

\subsection{Baseline Comparisons}

If the randomization was successful, the baseline characteristics of those not offered training (i.e., the control group) and those offered (i.e., the treatment group) should not be significantly different at least within training institutions. They could, however, differ between training institutions because these may differ in their quality and applicants may sort by training institution on the basis of tastes, ability and other variables that could affect the final outcomes. Moreover, the probability of assignment to treatment differs by training institution because in some cases there were not enough qualified applicants to assign $2 / 3$ to the treatment group and $1 / 3$ to the control group as in

\footnotetext{
${ }^{15}$ Moderate poverty is roughly defined as $\$ 2.00$ per day and extreme poverty as $\$ 1.00$ per day (World Development Report, 2001).
} 
the original design. For this reason, in addition to the simple comparison between treatment and control variable at baseline, we also make the same comparison allowing for training institution fixed effects. This second set of comparisons are thus based on within training institution contrasts. ${ }^{16}$

Table 3 reports differences in demographic characteristics and labor market outcomes between women in the treatment and control groups. The first column reports simple comparisons and the second allows for training institution fixed effects. The first column shows that treatment and control group characteristics are, for the most part, very similar for women at baseline, i.e., before the program. The only exceptions are education and age, which show significant but small differences between the two groups. The treatment group has a third of a year more education and is a fifth of a year younger than the treatment group. In addition, those in the treatment group appear to have one more month of tenure in their pre-treatment jobs. Controlling for institution fixed effects and thus comparing within training institution does not change the picture much, except for the fact that the difference in the pre-program tenure is no longer significant. The differences in education and age remain, although they only represent about $15 \%$ of a standard deviation for education and $10 \%$ for age.

Table 4 reports similar differences between those in the treatment and control groups to those reported in Table 3 but for men. These comparisons show that baseline characteristics are also fairly well balanced for men. As for women, there are small differences in education and age between men in the treatment and control groups. However, self-employment earnings are also significantly lower for men in the treatment

\footnotetext{
${ }^{16}$ Because training institutions are only identified in the follow-up sample, these comparisons within training institutions are based on the smaller follow-up sample. Comparisons for the restricted follow-up sample (not reported here) are very similar.
} 
group, although the discrepancy is only $13 \%$ of a standard deviation. ${ }^{17}$ In addition, treated individuals are more likely to have paid employment. ${ }^{18}$ When we control for institution fixed effects, only the differences in age, education and self-employment income remain significant at the $5 \%$ level, but these only represent $15 \%$ of a standard deviation for age and $13 \%$ of a standard deviation for education and self-employment. ${ }^{19}$

\section{Estimating Program Effects}

Define by $Y_{1 i}$ and $Y_{0 i}$ the outcomes for individual $i$ in the training state and the non-training state; $D_{i}=\{0,1\}$ the indicator of whether an individual chooses to participate in the program and is pre-selected by the training institution to which he applied. $R_{i}=$ $\{0,1\}$ is the indicator of whether the individual was (randomly) offered a place in the program, following pre-selection by a training institution. Finally, $\mathrm{E}\{\bullet\}$ represents expectations.

Given the design of the program, we have that the average outcome for those offered a place in training institution $\mathrm{T}$ is $\mathrm{E}\left\{\mathrm{Y}_{1 \mathrm{i}} \mid \mathrm{D}_{\mathrm{i}}=1, \mathrm{~T}\right\}=\mathrm{E}\left\{\mathrm{Y}_{1 \mathrm{i}} \mid \mathrm{D}_{\mathrm{i}}=1, \mathrm{~T}, \mathrm{R}_{\mathrm{i}}=1\right\}$. Similarly, the counterfactual for this population may be estimated using the average outcome for those randomized out of training, i.e., $\mathrm{E}\left\{\mathrm{Y}_{0 \mathrm{i}} \mid \mathrm{D}_{\mathrm{i}}=1, \mathrm{~T}\right\}=\mathrm{E}\left\{\mathrm{Y}_{0 \mathrm{i}} \mid \mathrm{D}_{\mathrm{i}}=1, \mathrm{~T}, \mathrm{R}_{\mathrm{i}}=0\right\}$. The difference between these two expectations is the program effect in training centre $\mathrm{T}$,

$$
\delta_{\mathrm{T}}=\mathrm{E}\left\{\mathrm{Y}_{1 \mathrm{i}}-\mathrm{Y}_{0 \mathrm{i}} \mid \mathrm{D}_{\mathrm{i}}=1, \mathrm{~T}\right\}=\mathrm{E}\left\{\mathrm{Y}_{1 \mathrm{i}} \mid \mathrm{D}_{\mathrm{i}}=1, \mathrm{~T}, \mathrm{R}_{\mathrm{i}}=1\right\}-\mathrm{E}\left\{\mathrm{Y}_{0 \mathrm{i}} \mid \mathrm{D}_{\mathrm{i}}=1, \mathrm{~T}, \mathrm{R}_{\mathrm{i}}=0\right\}
$$

\footnotetext{
${ }^{17}$ As explained in the Data Appendix, self-employment earnings are earnings of the self-employed net of business-related expenditures.

${ }^{18}$ As for women, comparisons restricted to the follow-up sample are very similar.

${ }^{19}$ Note that significant difference could emerge in any randomization. We examine differences for a large number of characteristics and outcomes and yet the vast majority of these differences are insignificant. Moreover, the fact that the few variables that are significant move in different direction for women and men, except for education, is also encouraging.
} 
Our estimator of the intention to treat is thus obtained as a weighted average of the within training centre effects, i.e.

$$
\hat{\delta}=\frac{\sum_{s} P_{s}\left(1-P_{s}\right)\left(\bar{Y}_{1 s}-\bar{Y}_{0 s}\right)}{\sum_{s} P_{s}\left(1-P_{s}\right)}
$$

where $P_{s}$ is the probability of selection into the program among qualified applicants in training institution $s, \bar{Y}_{1 s}$ is the average outcome (wages, employment, etc.) for those qualified applicants randomly offered training in institution $s$ and $\bar{Y}_{0 \mathrm{~s}}$ is the average outcome for those qualified applicants randomly denied training in institution $s$. The sum is taken over training institutions and the parameter is the weighted average of the program effects across training institutions. ${ }^{20}$ This simple comparison of weighted means is an unbiased estimate of $\delta$, the intention-to-treat (ITT) effect.

Recognizing that this is the standard within-groups estimator, it is straightforward to control for observable characteristics (see Arellano (2003)). Indeed, we control for age, education, a head status dummy, marital status, and city effects, all measured before training (pre-treatment) and henceforth denoted $\mathrm{X}_{\mathrm{i}}$. Including these pre-treatment characteristics increases the precision of the estimates and helps control for any remaining baseline imbalances, although these are insignificant for the most part and very small otherwise. In the tables below we report both the estimates that only control for

\footnotetext{
${ }^{20}$ Note that comparing within training institutions would not be necessary if the probability of assignment of the treatment group did not vary by training institution or if the effectiveness of training did not differ by training institution. As discussed above, the probability of treatment varies by training institution with a mean of 0.85 . Moreover, given the diversity of courses offered, the effectiveness of training is likely to vary across training institutions.
} 
training institution fixed effects and those that, in addition, control for the additional variables.

Given full compliance with the random assignment, the ITT parameter just described is the average effect of training on those who were deemed eligible and selected into the program. As shown in the next section, there was indeed close to full-compliance with this program.

\subsection{Effects of Random Offers on the take-up of Training}

The description of the data above suggested that few individuals who were randomly offered training turned down training opportunities and few individuals not initially offered a spot in a training institution eventually got trained. To examine how close random training offers relate to actual training, we estimate a linear probability model of training on a random offer indicator, controlling for training institution fixed effects and pre-treatment characteristics, as follows:

$$
\mathrm{T}_{\mathrm{ij}}=\alpha \mathrm{R}_{\mathrm{i}}+\rho \mathrm{X}_{\mathrm{i}}+\tau_{\mathrm{j}}+\mathrm{v}_{\mathrm{ij}}
$$

where $T_{i j}$ is an indicator of whether person $i$ obtained training in institution $j, X_{i}$ are pretreatment characteristics, $\tau_{\mathrm{j}}$ are training institution fixed effects and $v_{\mathrm{ij}}$ is a random error term. Table 5 reports the results of this regression for women and men separately. Random assignment to training increases women's probability of being trained by 0.96 and men's probability of training by 0.97 . Thus, there is close to full compliance in the sense that most of those initially assigned to training get trained and most of those not initially assigned to the program remain untrained. 


\subsection{Employment and Earnings Effects for Women}

Panel A of Table 6 presents ITT effects for women, which condition on training institution fixed effects and city effects. These results show positive effects of being offered training on employment, paid employment, days worked per month, hours worked per week, and wage and salary earnings. On the other hand, tenure declines and profits of the self-employed are not affected by training.

Panel B presents results which, in addition, control for pre-training characteristics. The results conditioning on pre-treatment characteristics are somewhat smaller but remain large and significant. The results show that being offered training increases the probability of employment and paid employment by 0.047 and 0.052 , respectively, as opposed to the 0.057 and 0.065 found without pre-treatment characteristics. Women's days and hours worked also increase after being offered training by close to a day and two and a half hours. The results for salaries also show smaller but still sizeable effects of being offered training of about $18 \%$ compared to the control group.

At this point, however, it is useful to see how we can interpret the comparisons of earnings (including the zeros) between treatment and control. The treatment effect we estimate is $E\left(S_{i} \mid R_{i}=1\right)-E\left(S_{i} \mid R_{i}=0\right)$, where $S_{i}$ stands for earnings (salary) and is set to zero if a person is out of work. Ignoring the pre-treatment characteristics for notational simplicity, this effect can be decomposed as

$$
\begin{gathered}
E\left(S_{i} \mid R_{i}=1\right)-E\left(S_{i} \mid R_{i}=0\right)=\left[E\left(S_{i} \mid P_{i}=1, R_{i}=1\right)-E\left(S_{i} \mid P_{i}=1, R_{i}=0\right)\right] \operatorname{Pr}\left(P_{i}=1 \mid R_{i}=0\right)+ \\
{\left[\operatorname{Pr}\left(P_{i}=1 \mid R_{i}=1\right)-\operatorname{Pr}\left(P_{i}=1 \mid R_{i}=0\right)\right] E\left(S_{i} \mid P_{i}=1, R_{i}=1\right)}
\end{gathered}
$$


This expression shows that earnings increases will occur because of increased employment (the last term) and/or because of the increased earnings of those employed. Earnings of those employed could increase either because worker productivity increased as a result of the program or because the intervention changes the composition of those working. Indeed this last effect could lead to a change in earnings even if the overall employment rate does not change. ${ }^{21}$ Our results suggest that about a third of the increase in salaries can be accounted for by increases in employment and the rest is due to higher earnings among those employed who received the treatment relative to the controls. Although the positive effect does mean that the program caused average earnings to rise, the mechanism by which this happens is not revealed by this sort of approach and could be due to increased productivity; due to the better quality of jobs obtained after training or due to employment composition effects. To get around the effects of censoring and to understand more about the mechanisms further assumptions and modeling is required. ${ }^{22}$

Returning to the results, the negative effects of being offered training on tenure are slightly larger and suggest a reduction in tenure of about one month and a half, or half of the time of the classroom training. The results controlling for pre-treatment characteristics, thus, confirm that the differences are not simply driven by the small preexisting differences between the two groups, which we described earlier.

\footnotetext{
${ }^{21}$ The composition of those working among those who received the intervention may be different than among those who did not.

22 For understanding more about the mechanisms an alternative would be to bound the impact on the quantiles of earnings for those in employment, using the approach developed by Manski (1994) and Blundell, Gosling, Ichimura and Meghir (2007). Here it would just about be possible to bound the effect at the median for women, whose participation in paid employment among the controls is $54 \%$, and the percentiles between the $30^{\text {th }}$ and the $70^{\text {th }}$ percentile for men. However, given the large number of individuals without employment, the bounds are likely to be very wide. Means cannot be bounded without assumption on the support of wages. This is, of course , a feature of any randomized experiment attempting to measure the effects on earnings, when there exists the possibility of non-employment.
} 
The picture is one of increased labor market activity with substantially higher wage and salary earnings and increased employment for women. On the basis of these results, this seems like a highly successful program for young women seeking training in the first place.

\subsection{Employment and Earnings Effects for Men}

Table 7 reports ITT effects for men. The results in Panel A, which condition on training institution fixed effects, show that training offers only increase wage and salary earnings in the case of men. On the other hand, these results show a reduction in tenure of about 3 months and a reduction in the earnings of the self-employed that are offered training. In Panel B we also control for pre-training age, household headship, marital status, and profits, the variables that displayed some small baseline differences. These results continue to show positive and significant effects of training on wage and salary earnings and negative effects on tenure and self-employment earnings, though the latter is only marginally significant. Those offered training earn 22,603 Colombian pesos or $8 \%$ more in salaried employment than those in the control group. Since there is no employment effect for men, the entire increase is coming from an increase in earnings of those working following the intervention relative to those working in the control group. ${ }^{23}$ On the other hand, men offered training earn about 9,326 Colombian pesos or $24 \%$ less in self-employment than those in the control group. This may simply reflect the movement of trainees from self-employment to salary employment and, as discussed below, into the formal sector. Also, even after controlling for pre-treatment characteristics, the results

\footnotetext{
${ }^{23}$ As already discussed, this in itself does not exclude the possibility that the observed increase is due to differences in composition of the two groups.
} 
continue to show a reduction in tenure of about two and half months or close to the time spent by trainees in the classroom.

To summarize: the results imply that training has had positive labor market impacts for both men and women but possibly through different mechanisms. For women there is a clear effect on employment, days, and hours as well as wage and salary earnings. For men the picture is different; the estimates imply an increase in the average wage and salary earnings among treated employed workers and a marginally significant decline in self-employment earnings, but no effect on employment rates. For women, a third of the increase can be attributed to increased employment. The rest is due to increased earnings among treated employed workers. For both women and men wage and salary earnings gains could also be related to access to better paid formal sector jobs.

The only other similar intervention with a randomized trial is that reported in Card et al. (2007) for the Dominican Republic and it is interesting to provide a brief comparison. The programs are similar with the only difference that in Colombia the internship lasted 3 months instead of 2 months as in the Dominican Republic. Card et al. (2007) find no employment effect, but they do find an earnings effect of $10 \%$ to $17 \%$ (depending on the method used). However, the effect they find is not precisely estimated. There are some differences in the design of the experiment and the data collection. First, the Card et al. (2007) sample has 786 treatment and 563 controls as opposed to the 1,749 treatment and 1,814 control individuals in our sample. This can explain a reduction of standard errors by a factor of 1.62 in our study. Second, our results are based on the original random assignment of treatment, while the Card et al. (2007) study had to use data on the realized training outcome. Given that in the Dominican Republic there was 
substantial reassignment after the dropping out of the originally assigned trainees, this could introduce bias. Nevertheless, the comparison between the two evaluations is valuable because of the similarity in program design and similarity in the magnitude of the results.

\subsection{Effects on Formal Sector Employment}

In Latin America, like in other developing countries, there is a large share of workers employed in the shadow or informal economy, with no coverage of mandatory benefits. About $45 \%$ of all workers in Colombia are employed in jobs in the informal sector, in which they do not receive non-wage benefits such as health insurance, pensions, or injury compensation. Moreover, earnings are lower on average in the informal sector, although this could be due to skills and/or self-selection by ability. ${ }^{24}$ It is, thus, important to ask whether the intervention improved access to the formal sector.

Table 8 shows intention-to-treat effects on the probability of formal employment, defined as employment covered by health, pension and injury compensation benefits, as well as on the probability of having a written contract. Not being employed in the formal sector includes the unemployed and those in the informal sector.

Panel A shows results controlling for training institution fixed effects and Panel B adds controls for pre-treatment characteristics, which includes a pre-treatment contract indicator in the case of men. The results show positive and significant effects on the probability of having a formal sector job and of having a written contract for both women and men. Training increases the probability of having a formal sector job by 0.053 and 0.052 for women and men, respectively. Training also increases the probability of having a written contract by 0.054 and 0.07 for women and men.

\footnotetext{
${ }^{24}$ See, e.g., Kugler (1999, 2005).
} 
In addition to estimating the effect of the program on the probability of formal employment, we also try to get at whether the impact of training on wage and salary earnings that we documented earlier is due to higher earnings in these formal sector jobs. For this purpose, we estimate separate regressions of formal and informal wage and salary earnings, where formal earnings are assigned a zero when individuals are employed in the informal sector and where informal earnings are assigned a zero when individuals are employed in the formal sector. Training increases wage and salary earnings in the formal sector but not in the informal sector for both women and men, indicating that the wage and salary earnings gains observed above are related to increased access to formal sector jobs

\subsection{Gender Differences}

The results above show larger and more widespread effects of training on women than on men. Women not only experience larger gains than men in terms of earnings following training, but they also experience gains in the quantity of employment in terms of participation, days and hours worked not experienced by men. There are three possible reasons for the differential returns to training for women relative to men. First, the higher return could result from the fact that women have lower levels of formal education to begin with. However, contrasting formal schooling at baseline in Table 2 shows small differences in education between women and men. Moreover, interaction models which allow for a differential effect of training for those with different education levels show no differences in the returns to training for more and less educated individuals. Second, women with children received an additional stipend for child care, which may have freed up additional time for women to devote to training. In fact, women tend to enroll in 
courses requiring longer hours, though as we will show below this does not seem to be an important part of the story. Third, qualitative interviews with the training institutions and trainees suggest that women were more motivated and were more responsible during the classroom and internship phases of the program. In fact, self-reported information on completion of the program show that $3.3 \%$ of men dropped out during the first three months of the program while only $2.4 \%$ of women did. Also, only $0.4 \%$ of women were expelled from the classroom or internship phases, while $1.3 \%$ of men were expelled. This may just reflect a different quality of original applicants to the program (in terms of unobservables) among men and women.

\subsection{Classroom vs. On-the-Job Training}

By most standards, including by cost-benefit criteria (which follow this section) this Colombian program is a resounding success. This does contrast with results obtained in industrialized countries, such as the US, the UK and others, as discussed earlier. A priori, there is little reason to expect that in such different contexts the results should be similar. However, it is still interesting and important to document, to the extent possible, what aspects of this program have made it successful.

We can isolate two important characteristics of the program. First, it included a substantive element of on-the-job training, which consisted of a 3-month internship. Second, private sector institutions - some for-profit and some nonprofit, offered the training and chose, designed and marketed the courses. There is already some evidence that both these aspects are important for the success of training programs. ${ }^{25}$ Here, we exploit variation in some aspects of this program to provide some indications of which of

\footnotetext{
${ }^{25}$ Sianesi (2003) for example shows that among the Swedish programs the ones relating to wage subsidies and internships are the most successful. Blundell, Dearden and Meghir (1996) show that private employer provided training is the one with positive returns.
} 
the aspects have been most important for its success. Of course the allocation of trainees to the various types of courses and training institutions is not random, so these results should be viewed as suggestive.

Table 9 shows the results of specifications that interact the treatment effect with classroom training characteristics. Panel A presents the results of models which include the interaction of the training offer dummy with the number of hours of training in the classroom. Panel B shows the results of models which include an interaction of the training offer dummy with a for profit training institution dummy. Neither the intensity of classroom training nor the for profit status of training institutions appear to affect the benefits to training in terms of overall and formal sector employment or earnings.

By contrast, the results in Panel A of Table 10, which include an interaction between the training offer dummy and hours of on-the-job training, show that employment and earnings gains are greater the longer the duration of on-the-job training. Moreover, Panel B in Table 10 shows models with an interaction of the training offer dummy with a dummy that takes the value of 1 , if the skills taught in the classroom and on-the-job training were the same, and zero otherwise. These results show bigger employment and earnings gains when the content of the classroom and on-the-job training coincided.

These results suggest that the intensity of on-the-job training was related to the success of the program, while the intensity of classroom training (within the range observed in our program) was irrelevant. Moreover, while the type of the training institution did not affect the returns to training, the similarity in content between the classroom and on-the-job training did matter. 
These findings suggest that it was the on-the-job component of the program that mattered in terms of the success of the program. In what follows, we show that these higher returns to training we find here also imply that these programs are cost-effective in a developing country context.

\section{Cost-Benefit Analysis}

The simplest way of calculating a lower bound to the benefits of the program is to use the gains in wage and salary earnings. ${ }^{26}$ The results imply a gain of about 30,000 for women and of about 22,000 for men, so there are yearly gains of 360,000 and 264,000 for women and men, respectively. The key question of course is whether these gains are permanent or not. We will consider two scenarios: one in which the gains are permanent but do not grow over time, and a second one in which we assume a $10 \%$ depreciation rate of these gains. We assume that the working life of these individuals is another 40 years, given that their average age is about 22 in the data. For women, the 30,000 Colombian pesos increase reflects employment and monthly earnings gains as well as the salary gains from moving to the formal sector for those who do so due to the program. In the case of men, the increase of 22,000 Colombian pesos reflects both monthly earnings gains as well as any salary gains from moving to the formal sector. Discounting at 5\% a year, and assuming the growth rate of earnings is not affected, we obtain a gain for women of $6,486,048$ Colombian pesos or about US\$3,212 and a gain for men of

\footnotetext{
${ }^{26}$ We do not actually need to know the mechanism by which salary increases for the treatment group so long as no one is negatively affected by the program. However, there is a possibility that some of the gain could have resulted in displacing individuals not trained due to a preference of employers for trained individuals. In this case, there is a cost to the program in terms of the lost earnings of those individuals. Such displacement effects and more generally the general equilibrium aspect of the intervention are important for understanding the longer term effects of such a program. From an experimental point of view one way to understand the importance of displacement is to randomize both between and within regions. Issues related to displacement are discussed in Blundell et al. (2004).
} 
$4,756,435$ Colombian pesos or US $\$ 2,355$ under the first scenario in which the gains are permanent. Under the more conservative scenario in which we allow the gains to depreciate at a rate of $10 \%$, the gains are of $2,514,694$ Colombian pesos or $\$ 1,245$ for women and of $1,844,109$ Colombian pesos or $\$ 913$ for men.

The direct cost of operation of the training program was US\$875 per person. In addition there is the cost of lost employment for those who would work at the time of training. We have seen that the loss of time in employment as measured by tenure due to time participating in the program is about 1 and a half months for women and 3 months for men. This is an overestimate of the employment loss because individuals could get many small jobs in one state and one long job in the other. Loss in tenure may not fully reflect unemployment. Table 2 reports an average monthly salary for women before training of 86,716 Colombian pesos or US $\$ 42$ per month and of 124,647 Colombian pesos or US\$60.57 for men. However, women get a transfer of $\$ 2.20$ daily if they do not have children under 7 and of $\$ 3.00$ if they have young children. Under either case, the stipend provided by the program more than compensates the monthly salary they would have gotten without the training, so the opportunity cost for women is zero. For men, the daily stipend of $\$ 2.20$ implies a monthly transfer of $\$ 44$, so the opportunity cost for men due to the three months of lost employment is $\$ 16.57$ per month or $\$ 49.71$ for the entire period. This implies a total cost of training of US\$875 for women and of US\$924.7 for men.

Under the first scenario of permanent gains, the net gains for women are of about $\$ 2,337$ and of about $\$ 1,430$ for men. Under the more conservative scenario which allows for depreciation of these gains, there is a net benefit of $\$ 370$ for women and a loss of $\$ 12$ 
for men. Thus, net benefits from the program are larger for women, but they are clearly positive for both genders when the gains are assumed to persist over time. However, when we allow for workers to lose some of the skills learned during training, the program is no longer cost-effective for men. On the other hand, this is clearly a conservative estimate given that we have not considered the non-wage benefits received due to the increased employment in the formal sector for both women and men.

Another way of calculating the effectiveness of the program is to calculate the internal rate of return. The internal rate of return is the rate of return that equates the costs with the gains. Under the first scenario the internal rate of return is $25 \%$ for women and $16 \%$ for men, while under the second scenario, which allows for depreciation, the rate of return is $13.5 \%$ for women and $4.5 \%$ for men. These high rates of return, especially for women, suggest that the training program is a great success, at least when interest rates are lower than $4.5 \%$.

The high returns to training beg the question as to why more people are not getting trained on their own. In the case of "Jóvenes en Acción", there was a shortage of volunteers for some courses once the program was announced, which suggests that lack of information may be preventing people from obtaining training. In addition, a credible hypothesis is that they cannot finance it. Indeed, for men it would take about 15 months pay to cover the entire cost, based on the average pay at the time of the program. Given the lower salaries for women, the cost of training for women corresponds to about 21 months of work. Moreover, the costs would be even higher for women with children who would need to cover for childcare costs during their participation in the program. It is 
unlikely that anyone would be able to borrow such an amount without collateral at a reasonable interest rate.

\section{Conclusion}

The program "Jóvenes en Acción" introduced in Colombia in 2005 offers a unique opportunity to evaluate the causal effect of training on young people with little education in the context of a less-developed country. The program offered vocational training for a total period of 6 months ( 3 months in classroom and 3 months on-the-job) to young unemployed women and men, who belonged to the lowest two strata in the population and who were for the most part high-school dropouts. Most importantly for the purpose of this evaluation, the program randomly offered training to these young women and men.

The results show that the program had substantial effects on both women and men, but in different ways. In particular, training increased wage and salaried earnings, the probability of employment, days and hours worked, the probability of having a formal job, and the probability of having a job with a written contract for women. The effects on men were smaller and also more limited. In the case of men, training only increased wage and salaried earnings, the probability of having a formal job, and the probability of having a job with a written contract, but not employment. Salaried earnings increased for both genders: $18 \%$ for women and $8 \%$ for men. In addition, we find an increase in the probabilities of having a formal sector job and a written contract for both women and men of about 0.05 and 0.07 , respectively. As is standard in these interventions, there is some loss in work experience for both women and men due to the time in the classroom, 
which is reflected in loss of tenure for the treatment group. In particular, we find a decrease of about one and a half and three months for women and men, respectively. The results are robust to controlling for training institution fixed effects and pre-treatment characteristics. This is reassuring, but not surprising, given the randomized design of the evaluation and the fact that treatment and control samples are reasonably balanced at baseline.

These results constitute the basis for a cost-benefit analysis. Even the most conservative of the cost-benefit calculations, which ignore the benefits associated to the higher probability of being employed in the formal sector and which allow the benefits to depreciate over time, suggest that the net benefits of the program more than justify its existence and possibly its expansion for women. Under this scenario, the internal rate of return is of $13.5 \%$ for women and $4.5 \%$ for men. Given the higher returns to training, the question remains as to why similar type of programs are not more widespread and why people do not take advantage of existing training opportunities. Lack of information and credit constrains are two likely causes, but this remains an open question.

An especially interesting and strong finding is the much bigger return to training for both women and men as the intensity of on-the-job training increases. By contrast, the returns to training do not respond to changes in intensity of classroom training, suggesting that it was the on-the-job component of the program that made the program a success. This findings echo some of the finding in the U.S. literature on training programs, which finds bigger effects of on-the-job than classroom training. The importance of on-the-job training combined with the strong effects on training on formal sector employment and earnings suggest that the program may have played a role in 
matching and placing workers by providing information to both sides of the market. In fact, one of the important roles played by the training program was to identify the demand for skills and place workers for the on-the-job component of the program. This is in line with the recent recommendation by Economic Commission for Latin America and the Caribbean (ECLAC) "[to establish] a national training and skills development system which provides internships in business and links to employers" as a solution to the youth unemployment problem in the region (Hopenhayn (2002)). 


\section{References}

Ado, Christian and Sergio Nuñez. 2004. "The Impact of Training Policies in Latin America and the Caribbean: The Case of Program Jove," IDB Working Paper No. R-483.

Arellano Manuel. 2003. Panel Data Econometrics. Oxford University Press

Ashenfelter, Oley. 1978. "Estimating the Effects of Training Programs on Earnings," Review of Economics and Statistics, 60: 648-660.

Blundell, Richard, Lorraine Dearden and Costas Meghir. 1996. "The Determinants and Effects of Work Related Training in Britain,” Mimeo, Institute for Fiscal Studies.

Blundell, Richard, Monica Costa Dias, Costas Meghir and John Van Reenen. 2004. Evaluating the Employment Impact of a Mandatory Job Search Assistance Program. Journal of the European Economic Association. 2(4): 569-606.

Blundell, Richard, Amanda Gosling, Hidechiko Ichimura and Costas Meghir. 2007. "Changes in the Distribution of Male and Female Wages Accounting for Employment Composition Using Bounds," Econometrica, 75(2): 323-363.

Burghardt, John and Peter Schochet. 2001. "National Job Corps Study: Impact by Center Characteristics," Princeton: Mathematica Policy Research.

Card, David, Pablo Ibarrarán, Ferdinando Regalia, David Rosas, and Yuri Soares. 2007. "The Labor Market Impact of Youth Training in the Dominican Republic: Evidence from a Randomized Evaluation," NBER Working Paper No. 12883.

Card, David and Daniel Sullivan. 1988. "Measuring the Effect of Subsidized Training Programs on Movements In and Out of Employment," Econometrica, 56: 497-530.

Calderon-Madrid, Angel. 2006. "Revisiting the Employability Effects of Training Programs for the Unemployed in Developing Countries," IDB Working Paper No. R-522.

Chong, Alberto and José Galdo. 2006. "Training Quality and Earnings: The Effects of Competition on the Provision of Public-Sponsored Training Programs," Mimeo.

Elias, Victor, Fernando Ruiz, Ricardo Cossa, and David Bravo. 2004. "An Econometric Cost-Benefit Analysis of Argentina's Youth Training Program," IDB Working Paper No. $\mathrm{R}-482$.

Gill, Indermit, Claudio Montenegro and Dörte Dömeland. 2002. Crafting Labor Policy: Techniques and Lessons from Latin America. Washington, D.C.: The World Bank.

Heckman, James and Alan Krueger. 2003. Inequality in America: What Role for Human Capital Policies? Cambridge, Mass.: MIT Press. 
Heckman, James, Robert LaLonde and Jeffrey Smith. 1999. "The Economics and Econometrics of Active Labor Market Programs," in Oley Ashenfelter and David Card, eds. Handbook of Labor Economics, Vol. 3A, pp. 1865-2097.

Heckman, James, Hidehiko Ichimura, Jeffrey Smith, Petra Todd. 1998. "Characterizing Selection Bias Using Experimental Data,” Econometrica, 66(5): 1017-1098.

Hopenhayn, Martin. 2002. "Youth and Employment in Latin America and the Caribbean: Problems, Prospects and Options," ECLAC Working Paper.

Ibarrarán, Pablo and David Rosas. 2007. "Impact Evaluation of Labor Training Program in Panama," Mimeo.

Kugler, Adriana. 2005. "Wage-Shifting Effects of Severance Payments Savings Accounts in Colombia," Journal of Public Economics, 89(2-3): 487-500.

Kugler, Adriana. 1999. "The Impact of Firing Costs on Turnover and Unemployment: Evidence from the Colombian Labor Market Reform," International Tax and Public Finance Journal, 6(3): 389-410.

LaLonde, Robert. 1986. "Evaluating the Econometric Evaluations of Training Programs with Experimental Data," American Economic Review, 76(4): 604-620.

Manski, C. (1994): "The Selection Problem," in Advances in Econometrics, Sixth World Congress, Vol 1, ed. by C. Sims. Cambridge, U.K.: Cambridge University Press, 143170. $[327,329,331]$

Orr, Larry, Howard Bloom, Stephen Bell, Winston Lin, George Cave and Fred Doolittle. 1994. The National JTPA Study: Impacts, Benefits, and Costs of Title II-A. Bethesda, Md.: Abt Associates.

Smith, Jeffrey and Petra Todd. 2001. "Reconciling Conflicting Evidence on the Performance of Propensity Score Matching Methods," American Economic Review, 91(2): 112-118.

Sianesi, Barbara. 2003. "Swedish Active Labour Market Programmes in the 1990s: Overall Effectiveness and Differential Performance," Swedish Economic Policy Review, 8(2): 133-169.

World Bank. 2007. World Development Report. Washington D.C.: The World Bank. 


\section{Data Appendix}

All information used in this analysis was originally collected for the purpose of evaluating the program "Jóvenes en Acción." The data was collected by enumerators which visited the household of individuals in the treatment and control groups on average 3 times. The survey consisted of three parts. The first part collected information on the characteristics of the household, including demographic characteristics of all members of the household as well as household expenditures. The second part of the survey collected information on education, general labor market experience and health outcomes of all household members over the age of 12. Finally, the last part of the survey collected detailed labor market information exclusively on young individuals assigned either to the treatment or control groups. The information in the filled surveys was scanned; read by computers, and subsequently checked for reading errors.

Employment and Paid Employment: the employment variable is an indicator variable which takes the value of 1 if the person reports to have had a job during the year after finishing training or 0 if the person reports being unemployed or out of the labor force. Paid employment is slightly different as it also assigns a value of zero to those who report being employed but who report having zero earnings. There are 176 women and 179 men who report having being employed but having earnings of zero.

Weeks and Hours Worked: the survey asks the weeks worked per month and the hours worked per week on the main job held during the year after finishing training. We impute zero weeks and hours worked for all of those who reported being either unemployed or out of the labor force during the year following the completion of the training program.

Formal Employment: formal employment is an indicator variable which takes the value of 1 if the worker was covered by health insurance, injury compensation, pensions or family subsidies, and zero if the worker did not receive any of these benefits in the main job held during the year after having finished training. We impute zeros for all individuals who report being either unemployed or out of the labor force during the entire year after the completion of the program.

Written Contract: written contract is an indicator variable which takes the value of 1 if the person reports having signed a written contract in the most important job during the year following the completion of the program and zero if the person did not sign a contract in the most important job or was unemployed or out of the labor force during the year following the completion of the program. Note that this is different from having a permanent or a temporary contract, but rather refers to having any type of written contract whatsoever.

Tenure: the tenure on the most important job during the year following the completion of the program is constructed by using the exact dates (month and year) when the person reported ending and starting the most important job held during the year after the completion of the program. For those who reported to still be in the same jobs, the end date used was the month and year of the interview so that tenure spells were incomplete. 
We also imputed zero tenure spells for all individuals who reported being unemployed or out of the labor force during the year following the completion of the training program.

Wage and Salary Earnings and Self-Employment Earnings: wage and salary earnings are the monthly salaries and wages earned in the main job held during the year after having finished training for salaried workers. Self-employment earnings are the monthly earnings net of costs for the self-employed. We impute zero earnings for all of those who reported being either unemployed or out of the labor force. Earnings are deflated by a city-specific CPI, which comes from the National Department of Statistics (DANE).

Formal and Informal Wage and Salary Earnings: formal wage and salary earnings are the monthly salaries and wages earned in the main formal job held during the year after having finished training for salaried workers. Similarly, informal wage and salary earnings are the monthly salaries and wages earned in the main informal job held during the year after having finished training for salaried workers. We impute zero earnings for those who reported being either unemployed or out of the labor force. For formal earnings, we impute zero earnings for all of those who were identified as employed in the informal sector. By contrast, for informal earnings, we impute zero earnings for all of those who were identified as employed in the formal sector. As before, earnings are deflated by a city-specific CPI. 
Table 1: Proposed and Actual Sample Sizes for Pre and Post-Treatment Periods by City

\begin{tabular}{|c|c|c|c|c|c|c|}
\hline & \multicolumn{2}{|c|}{ Proposed Sample } & \multicolumn{2}{|c|}{ Baseline Sample } & \multicolumn{2}{|c|}{ Follow-up Sample } \\
\hline & Treatment & Control & Treatment & Control & Treatment & Control \\
\hline Bogotá & 625 & 741 & 642 & 712 & 528 & 530 \\
\hline Medellín & 378 & 441 & 386 & 442 & 333 & 378 \\
\hline Cali & 340 & 393 & 344 & 388 & 292 & 312 \\
\hline Barranquilla & 211 & 246 & 211 & 256 & 190 & 207 \\
\hline Bucaramanga & 207 & 212 & 204 & 212 & 161 & 146 \\
\hline Manizales & 99 & 93 & 99 & 93 & 81 & 77 \\
\hline Cartagena & 180 & 184 & 180 & 184 & 164 & 164 \\
\hline Total & 2,040 & 2,310 & 2,066 & 2,287 & 1,749 & 1,814 \\
\hline
\end{tabular}

Notes: The table reports the proposed sample sizes for the treatment and control groups based on power tests of a significance difference in earnings and employment between the two groups at the 10 percent level. The baseline sample reports the actual sample sizes before training was provided and the follow-up sample reports the actual size of the sample collected after the training program. 
Table 2: Basic Descriptive Statistics of Pre- and Post-Treatment Variables for Women and Men

\begin{tabular}{|c|c|c|c|c|}
\hline & \multicolumn{2}{|c|}{ Women } & \multicolumn{2}{|c|}{ Men } \\
\hline & $\begin{array}{l}\text { Pre-Treatment } \\
2004\end{array}$ & $\begin{array}{l}\text { Post-Treatment } \\
2006\end{array}$ & $\begin{array}{l}\text { Pre-Treatment } \\
2004\end{array}$ & $\begin{array}{l}\text { Post-Treatment } \\
2006\end{array}$ \\
\hline Employment & $\begin{array}{c}0.465 \\
(0.499)\end{array}$ & $\begin{array}{c}0.670 \\
(0.470)\end{array}$ & $\begin{array}{c}0.587 \\
(0.493)\end{array}$ & $\begin{array}{c}0.830 \\
(0.376)\end{array}$ \\
\hline Paid Employment & $\begin{array}{c}0.340 \\
(0.474)\end{array}$ & $\begin{array}{c}0.578 \\
(0.494)\end{array}$ & $\begin{array}{c}0.404 \\
(0.491)\end{array}$ & $\begin{array}{c}0.720 \\
(0.449)\end{array}$ \\
\hline Contract (zero if out of work) & $\begin{array}{c}0.072 \\
(0.258)\end{array}$ & $\begin{array}{l}0.229 \\
(0.420)\end{array}$ & $\begin{array}{l}0.106 \\
(0.307)\end{array}$ & $\begin{array}{c}0.341 \\
(0.474)\end{array}$ \\
\hline Formal (zero if out of work) & $\begin{array}{c}0.070 \\
(0.256)\end{array}$ & $\begin{array}{c}0.231 \\
(0.421)\end{array}$ & $\begin{array}{c}0.120 \\
(0.325)\end{array}$ & $\begin{array}{c}0.382 \\
(0.486)\end{array}$ \\
\hline $\begin{array}{l}\text { Wage and Salary Earnings } \\
\text { (zero if out of work) }\end{array}$ & $\begin{array}{c}86,716 \\
(141,180)\end{array}$ & $\begin{array}{c}195,090 \\
(199,680)\end{array}$ & $\begin{array}{c}124,647 \\
(173,206)\end{array}$ & $\begin{array}{c}285,444 \\
(218,708)\end{array}$ \\
\hline $\begin{array}{l}\text { Self-employment Earnings } \\
\text { (zero if missing) }\end{array}$ & $\begin{array}{l}15,089 \\
(60,127)\end{array}$ & $\begin{array}{l}14,835 \\
(67,792)\end{array}$ & $\begin{array}{l}32,228 \\
(97,744)\end{array}$ & $\begin{array}{l}27,710 \\
(99,662)\end{array}$ \\
\hline Tenure (zero if out of work) & $\begin{array}{c}3.229 \\
(9.226)\end{array}$ & $\begin{array}{c}6.583 \\
(12.235)\end{array}$ & $\begin{array}{c}4.151 \\
(8.668)\end{array}$ & $\begin{array}{c}9.380 \\
(14.967)\end{array}$ \\
\hline $\begin{array}{l}\text { Days Worked per Month (zero } \\
\text { if out of work) }\end{array}$ & $\begin{array}{l}11.033 \\
(12.597)\end{array}$ & $\begin{array}{l}15.606 \\
(12.214)\end{array}$ & $\begin{array}{l}14.133 \\
(12.624)\end{array}$ & $\begin{array}{l}20.083 \\
(10.469)\end{array}$ \\
\hline $\begin{array}{l}\text { Hours Worked per Week (zero } \\
\text { if out of work) }\end{array}$ & $\begin{array}{c}22.776 \\
(28.084)\end{array}$ & $\begin{array}{c}33.460 \\
(27.979)\end{array}$ & $\begin{array}{c}29.864 \\
(28.954)\end{array}$ & $\begin{array}{c}44.183 \\
(24.940)\end{array}$ \\
\hline Education & $\begin{array}{c}9.978 \\
(1.872)\end{array}$ & $\begin{array}{l}10.247 \\
(1.677)\end{array}$ & $\begin{array}{l}10.131 \\
(1.773)\end{array}$ & $\begin{array}{l}10.316 \\
(1.721)\end{array}$ \\
\hline Age & $\begin{array}{l}21.326 \\
(2.050)\end{array}$ & $\begin{array}{l}22.869 \\
(2.060)\end{array}$ & $\begin{array}{l}20.940 \\
(2.023)\end{array}$ & $\begin{array}{l}22.542 \\
(2.117)\end{array}$ \\
\hline Married & $\begin{array}{c}0.269 \\
(0.444)\end{array}$ & $\begin{array}{c}0.324 \\
(0.468)\end{array}$ & $\begin{array}{c}0.109 \\
(0.311)\end{array}$ & $\begin{array}{c}0.181 \\
(0.385)\end{array}$ \\
\hline Max N & 2,321 & 1,926 & 2,028 & 1,632 \\
\hline
\end{tabular}

Notes: The table reports means and standard deviations of the labor market outcomes and demographic characteristics for the pre-training period and the post-training period, combining treatment and control groups. 
Table 3: Baseline Differences between Women in Treatment and Control Groups

\begin{tabular}{|c|c|c|}
\hline & $\begin{array}{c}\text { Pre-Training } 2004 \\
\text { (Pre-Training Sample) } \\
\text { No Institution Fixed } \\
\text { Effects }\end{array}$ & $\begin{array}{c}\text { Pre-Training } 2004 \\
\text { (Post-Training Sample) } \\
\text { With Institution Fixed } \\
\text { Effects }\end{array}$ \\
\hline Employment & $\begin{array}{c}0.011 \\
(0.022)\end{array}$ & $\begin{array}{c}0.009 \\
(0.023)\end{array}$ \\
\hline Paid Employment & $\begin{array}{c}0.025 \\
(0.021)\end{array}$ & $\begin{array}{c}0.028 \\
(0.022)\end{array}$ \\
\hline Contract (zero if out of work) & $\begin{array}{c}0.005 \\
(0.011)\end{array}$ & $\begin{array}{c}0.004 \\
(0.012)\end{array}$ \\
\hline Formal (zero if out of work) & $\begin{array}{c}0.014 \\
(0.012)\end{array}$ & $\begin{array}{c}0.009 \\
(0.012)\end{array}$ \\
\hline $\begin{array}{l}\text { Wage and Salary Earnings } \\
\text { (zero if out of work) }\end{array}$ & $\begin{array}{c}4,719 \\
(6,253)\end{array}$ & $\begin{array}{c}3,186 \\
(6,452)\end{array}$ \\
\hline $\begin{array}{l}\text { Self-employment Earnings } \\
\text { (zero if missing) }\end{array}$ & $\begin{array}{c}3,105 \\
(2,826)\end{array}$ & $\begin{array}{l}1,666 \\
(2,906)\end{array}$ \\
\hline Tenure (zero if out of work) & $\begin{array}{l}1.174^{* *} \\
(0.499)\end{array}$ & $\begin{array}{l}0.942^{*} \\
(0.541)\end{array}$ \\
\hline $\begin{array}{l}\text { Days Worked per Month } \\
\text { (zero if out of work) }\end{array}$ & $\begin{array}{c}0.585 \\
(0.555)\end{array}$ & $\begin{array}{c}0.344 \\
(0.581)\end{array}$ \\
\hline $\begin{array}{l}\text { Hours Worked per Week } \\
\text { (zero if out of work) }\end{array}$ & $\begin{array}{l}1.008 \\
(1.241)\end{array}$ & $\begin{array}{l}0.467 \\
(1.291)\end{array}$ \\
\hline Education & $\begin{array}{c}0.286 * * * \\
(0.088)\end{array}$ & $\begin{array}{c}0.329 * * * \\
(0.044)\end{array}$ \\
\hline Age & $\begin{array}{c}-0.202 * * \\
(0.085)\end{array}$ & $\begin{array}{l}0.221 * * \\
(0.090)\end{array}$ \\
\hline Married & $\begin{array}{l}-0.016 \\
(0.021)\end{array}$ & $\begin{array}{l}-0.029 \\
(0.022)\end{array}$ \\
\hline Max N & 2,321 & 1,920 \\
\hline
\end{tabular}

Notes: The table reports differences in mean characteristics between the treatment and control groups with and without controls for training institution fixed effects. The pre-training sample refers to the full sample at baseline. The post-training sample includes only those observations which were observed in the follow-up sample and which were not lost due to attrition. * indicates significance at the $10 \%$ level, $* *$ indicates significance at the $5 \%$ level, and $* * *$ indicates significance at the $1 \%$ level. 
Table 4: Baseline Differences between Men in Treatment and Control Groups

\begin{tabular}{|c|c|c|}
\hline & $\begin{array}{c}\text { Pre-Training } 2004 \\
\text { (Pre-Training Sample) } \\
\text { No Institution Fixed } \\
\text { Effects } \\
\end{array}$ & $\begin{array}{c}\text { Pre-Training } 2004 \\
\text { (Post-Training Sample) } \\
\text { With Institution Fixed } \\
\text { Effects } \\
\end{array}$ \\
\hline Employment & $\begin{array}{c}0.012 \\
(0.024)\end{array}$ & $\begin{array}{l}-0.002 \\
(0.025)\end{array}$ \\
\hline Paid Employment & $\begin{array}{l}0.046^{*} \\
(0.025)\end{array}$ & $\begin{array}{c}0.038 \\
(0.026)\end{array}$ \\
\hline $\begin{array}{l}\text { Contract (zero if out of } \\
\text { work) }\end{array}$ & $\begin{array}{l}-0.023 \\
(0.016)\end{array}$ & $\begin{array}{l}-0.029 * \\
(0.017)\end{array}$ \\
\hline $\begin{array}{l}\text { Formal (zero if out of } \\
\text { work) }\end{array}$ & $\begin{array}{l}-0.007 \\
(0.016)\end{array}$ & $\begin{array}{l}-0.028 \\
(0.018)\end{array}$ \\
\hline $\begin{array}{l}\text { Wage and Salary Earnings } \\
\text { (zero if out of work) }\end{array}$ & $\begin{array}{l}-1,817 \\
(8,759)\end{array}$ & $\begin{array}{l}-7,059 \\
(8,978)\end{array}$ \\
\hline $\begin{array}{l}\text { Self-employment Earnings } \\
\text { (zero if missing) }\end{array}$ & $\begin{array}{c}-14,051^{* *} \\
(5,718)\end{array}$ & $\begin{array}{c}-13,206^{* *} \\
(5,991)\end{array}$ \\
\hline $\begin{array}{l}\text { Tenure (zero if out of } \\
\text { work) }\end{array}$ & $\begin{array}{c}0.807 \\
(0.545)\end{array}$ & $\begin{array}{c}0.831 \\
(0.544)\end{array}$ \\
\hline $\begin{array}{l}\text { Days Worked per Month } \\
\text { (zero if out of work) }\end{array}$ & $\begin{array}{l}-0.188 \\
(0.624)\end{array}$ & $\begin{array}{l}-0.303 \\
(0.648)\end{array}$ \\
\hline $\begin{array}{l}\text { Hours Worked per Week } \\
\text { (zero if out of work) }\end{array}$ & $\begin{array}{l}-0.433 \\
(1.421)\end{array}$ & $\begin{array}{l}-1.031 \\
(1.457)\end{array}$ \\
\hline Education & $\begin{array}{c}0.340 * * * \\
(0.102)\end{array}$ & $\begin{array}{l}0.236^{* *} \\
(0.100)\end{array}$ \\
\hline Age & $\begin{array}{c}-0.293^{* * *} \\
(0.100)\end{array}$ & $\begin{array}{c}-0.310^{* * *} \\
(0.107)\end{array}$ \\
\hline Married & $\begin{array}{c}-0.033^{*} \\
(0.019)\end{array}$ & $\begin{array}{c}-0.032 \\
(0.020)\end{array}$ \\
\hline Max N & 2,028 & 1,626 \\
\hline
\end{tabular}

Notes: The table reports differences in mean characteristics between the treatment and control groups with and without controls for training institution fixed effects. The pre-training sample refers to the full sample at baseline. The post-training sample includes only those observations which were observed in the follow-up sample and which were not lost due to attrition. * indicates significance at the $10 \%$ level, $* *$ indicates significance at the $5 \%$ level, and $* * *$ indicates significance at the $1 \%$ level. 
Table 5: Effect of Training Offer on Probability of Being Trained

\begin{tabular}{lcc}
\hline \hline & Women & $\underline{\text { Men }}$ \\
\cline { 2 - 3 } Training Offer & $0.961^{* * *}$ & $0.965^{* * *}$ \\
& $(0.012)$ & $(0.007)$ \\
City Effects & Yes & Yes \\
& & \\
Pre-treatment Characteristics & Yes & Yes \\
Training Institution Effects & Yes & Yes \\
$\mathrm{R}^{2}$ & 0.92 & 0.94 \\
$\mathrm{~N}$ & 1,917 & 1,621 \\
\hline \hline
\end{tabular}

Notes: The table reports the effect of being randomly offered training on the probability of having being trained. Robust standard errors are in parenthesis. $* * *$ indicates significance at the $1 \%$ level or below. 
Table 6: Intention-to-Treat Estimates of Effects of Training on Employment and Earnings of Women

\begin{tabular}{|c|c|c|c|c|c|c|c|}
\hline \multirow[b]{4}{*}{$\begin{array}{c}\text { Control } \\
\text { Means }\end{array}$} & \multicolumn{5}{|c|}{ Labor Supply } & \multicolumn{2}{|c|}{ Earnings } \\
\hline & Employment & $\underline{\text { Paid }}$ & Days/Month & Hours/Week & Tenure & Wage \& Salary & Self-employment \\
\hline & & Employment & & & माinus & Earnings & $\underline{\text { Earnings }}$ \\
\hline & 0.636 & 0.535 & 14.572 & 31.203 & 7.483 & 171,371 & 14,667 \\
\hline & \multicolumn{7}{|c|}{ A. Training Institution Fixed Effects } \\
\hline \multirow{4}{*}{$\mathrm{N}$} & $\begin{array}{c}0.057 * * * \\
(0.021)\end{array}$ & $\begin{array}{c}0.065^{* * *} \\
(0.023)\end{array}$ & $\begin{array}{c}1.510^{* * *} \\
(0.561)\end{array}$ & $\begin{array}{c}3.332 * * * \\
(1.284)\end{array}$ & $\begin{array}{c}-1.540 * * * \\
(0.561)\end{array}$ & $\begin{array}{c}37,022 * * * \\
(9,184)\end{array}$ & $\begin{array}{c}3,487 \\
(3,080)\end{array}$ \\
\hline & 1,917 & 1,917 & 1,917 & 1,917 & 1,906 & 1,917 & 1,917 \\
\hline & \multicolumn{7}{|c|}{ B. Training Institution Fixed Effects and Pre-treatment Characteristics } \\
\hline & $\begin{array}{c}0.047 * * \\
(0.021)\end{array}$ & $\begin{array}{c}0.052 * * \\
(0.022)\end{array}$ & $\begin{array}{c}1.149 * * \\
(0.557)\end{array}$ & $\begin{array}{c}2.540 * * \\
(1.282)\end{array}$ & $\begin{array}{c}-1.604 * * * \\
(0.559)\end{array}$ & $\begin{array}{c}30,401 * * * \\
(9,111)\end{array}$ & $\begin{array}{c}3,465 \\
(2,941)\end{array}$ \\
\hline $\mathrm{N}$ & 1,917 & 1,917 & 1,917 & 1,917 & 1,906 & 1,917 & 1,917 \\
\hline
\end{tabular}

Notes: The table reports the coefficient of the training offer dummy for separate regressions of labor market outcomes. Robust standard errors are reported in parenthesis. All regressions control for training institution fixed effects. The regressions in Panel B control for pre-training age, headship status dummy, marital dummy, education, pregnancy, and city effects, and for pre-training tenure in tenure regression. * indicates significance at the $10 \%$ level, ${ }^{* *}$ indicates significance at the $5 \%$ level, and *** indicates significance at the $1 \%$ level. 
Table 7: Intention-to-Treat Estimates of Effects of Training on Employment and Earnings of Men

\begin{tabular}{|c|c|c|c|c|c|c|c|}
\hline \multirow{4}{*}{$\begin{array}{l}\text { Control } \\
\text { Means }\end{array}$} & \multicolumn{5}{|c|}{ Labor Supply } & \multicolumn{2}{|c|}{ Earnings } \\
\hline & Employment & $\underline{\text { Paid }}$ & Days/Month & Hours/Week & Tenure & Wage \& Salary & Self-employment \\
\hline & & Employment & & & Prinue & Earnings & Earnings \\
\hline & 0.847 & 0.704 & 20.464 & 46,225 & 11.521 & 277,302 & 38,229 \\
\hline & \multicolumn{7}{|c|}{ A. Training Institution Fixed Effects } \\
\hline \multirow{4}{*}{$\mathrm{N}$} & $\begin{array}{l}-0.004 \\
(0.020)\end{array}$ & $\begin{array}{c}0.036 \\
(0.023)\end{array}$ & $\begin{array}{c}0.093 \\
(0.546)\end{array}$ & $\begin{array}{l}-1.524 \\
(1.308)\end{array}$ & $\begin{array}{c}-2.876^{* * *} \\
(0.748)\end{array}$ & $\begin{array}{c}21,757 * \\
(11,463)\end{array}$ & $\begin{array}{c}-12,086^{*} \\
(5,231)\end{array}$ \\
\hline & 1,621 & 1,621 & 1,621 & 1,621 & 1,615 & 1,621 & 1,621 \\
\hline & \multicolumn{7}{|c|}{ B. Training Institution Fixed Effects and Pre-treatment Characteristics } \\
\hline & $\begin{array}{c}0.002 \\
(0.020)\end{array}$ & $\begin{array}{c}0.035 \\
(0.023)\end{array}$ & $\begin{array}{c}0.064 \\
(0.546)\end{array}$ & $\begin{array}{l}-1.064 \\
(1.308)\end{array}$ & $\begin{array}{c}-2.538 * * * \\
(0.753)\end{array}$ & $\begin{array}{c}22,603^{* *} \\
(11,309)\end{array}$ & $\begin{array}{c}-9,326^{*} \\
(5,184)\end{array}$ \\
\hline $\mathrm{N}$ & 1,621 & 1,621 & 1,621 & 1,621 & 1,615 & 1,621 & 1,621 \\
\hline
\end{tabular}

Notes: The table reports the coefficient of the training offer dummy for separate regressions of labor market outcomes. Robust standard errors are reported in parenthesis. All regressions control for training institution fixed effects. The regressions in Panel B control for pre-training age, headship status dummy, marital dummy, education, pregnancy, and city effects, and for pre-training tenure in tenure regression. * indicates significance at the $10 \%$ level, $* *$ indicates significance at the $5 \%$ level, and $* * *$ indicates significance at the $1 \%$ level. 
Table 8: Intention-to-Treat Estimates of Effects of Training on Formal Employment and Earnings of Women and Men

\begin{tabular}{|c|c|c|c|c|c|c|c|c|}
\hline & \multicolumn{4}{|c|}{ Women } & \multicolumn{4}{|c|}{ Men } \\
\hline & $\underline{\text { Contract }}$ & $\begin{array}{c}\underline{\text { Formal }} \\
\underline{\text { Employment }}\end{array}$ & $\frac{\text { Formal }}{\text { Salary }}$ & $\frac{\text { Informal }}{\underline{\text { Salary }}}$ & $\underline{\text { Contract }}$ & $\begin{array}{c}\underline{\text { Formal }} \\
\underline{\text { Employment }}\end{array}$ & $\underline{\text { Formal }}$ & $\frac{\text { Informal }}{\underline{\text { Salary }}}$ \\
\hline & \multicolumn{8}{|c|}{ A. Training Institution Fixed Effects } \\
\hline & $\begin{array}{c}0.070^{* * *} \\
(0.020)\end{array}$ & $\begin{array}{c}0.068 * * * \\
(0.020)\end{array}$ & $\begin{array}{c}33,404 * * * \\
(8,565)\end{array}$ & $\begin{array}{c}3,802 \\
(7,594)\end{array}$ & $\begin{array}{c}0.071 * * * \\
(0.024)\end{array}$ & $\begin{array}{c}0.050 * * \\
(0.025)\end{array}$ & $\begin{array}{c}30,932 * * \\
(12,137)\end{array}$ & $\begin{array}{l}-9,961 \\
(9,546)\end{array}$ \\
\hline $\mathrm{N}$ & 1,917 & 1,917 & 1,917 & 1,917 & 1,621 & 1,621 & 1,621 & 1,621 \\
\hline & \multicolumn{8}{|c|}{ B. Training Institution Fixed Effects and Pre-training Characteristics } \\
\hline & $\begin{array}{c}0.054^{* * * *} \\
(0.020)\end{array}$ & $\begin{array}{c}0.053 * * * \\
(0.020)\end{array}$ & $\begin{array}{c}26,831^{* * *} \\
(8,569)\end{array}$ & $\begin{array}{c}3,570 \\
(7,687)\end{array}$ & $\begin{array}{c}0.070 * * * \\
(0.024)\end{array}$ & $\begin{array}{c}0.052 * * \\
(0.025)\end{array}$ & $\begin{array}{c}29,990 * * \\
(11,956)\end{array}$ & $\begin{array}{l}-7.626 \\
(9,563)\end{array}$ \\
\hline $\mathrm{N}$ & 1,917 & 1,917 & 1,917 & 1,917 & 1,621 & 1,621 & 1,621 & 1,621 \\
\hline
\end{tabular}

Notes: The table reports the coefficient of the training offer dummy for separate regressions of labor market outcomes for women and men. Robust standard errors are reported in parenthesis. All regressions control for training institution fixed effects. The regressions in Panel B control for pre-training age, headship status dummy, marital dummy, education, and city effects, and for pre-training contract indicator in contract regression. * indicates significance at the $10 \%$ level, ** indicates significance at the $5 \%$ level, and $* * *$ indicates significance at the $1 \%$ level. 
Table 9: Effects of Quality of Classroom Training on Overall and Formal Employment and Earnings of Women and Men

\begin{tabular}{|c|c|c|c|c|c|c|c|c|}
\hline & \multicolumn{4}{|c|}{ Women } & \multicolumn{4}{|c|}{ Men } \\
\hline & $\frac{\text { Paid }}{\text { Employment }}$ & Salary & $\underline{\text { Formal }}$ & $\underline{\text { Formal }}$ & $\underset{\text { Employment }}{\underline{\text { Paid }}}$ & $\underline{\text { Salary }}$ & $\stackrel{\text { Formal }}{\text { Employment }}$ & $\underline{\text { Formal }}$ Salary \\
\hline & \multicolumn{8}{|c|}{ A. Interactions with Hours of Classroom Instruction } \\
\hline Training Offer & $\begin{array}{c}0.140 * * \\
(0.060)\end{array}$ & $\begin{array}{c}38,471 \\
(24,929)\end{array}$ & $\begin{array}{l}0.090 * \\
(0.051)\end{array}$ & $\begin{array}{l}36,142 * \\
(21,545)\end{array}$ & $\begin{array}{c}0.067 \\
(0.061)\end{array}$ & $\begin{array}{l}47,917 * \\
(29,564)\end{array}$ & $\begin{array}{c}0.054 \\
(0.062)\end{array}$ & $\begin{array}{c}27,321 \\
(29,872)\end{array}$ \\
\hline $\begin{array}{l}\text { Training Offer } \times \\
\text { Classroom Hours }\end{array}$ & $\begin{array}{l}-0.001 \\
(0.001)\end{array}$ & $\begin{array}{c}-94 \\
(306)\end{array}$ & $\begin{array}{l}-0.000 \\
(0.001)\end{array}$ & $\begin{array}{l}-61 \\
(272)\end{array}$ & $\begin{array}{l}-0.000 \\
(0.001)\end{array}$ & $\begin{array}{l}-416 \\
(377)\end{array}$ & $\begin{array}{l}-0.000 \\
(0.001)\end{array}$ & $\begin{array}{c}-86 \\
(385)\end{array}$ \\
\hline \multirow[t]{2}{*}{$\mathrm{N}$} & 1,915 & 1,915 & 1,915 & 1,915 & 1,402 & 1,402 & 1,402 & 1,402 \\
\hline & \multicolumn{8}{|c|}{ B. Interactions with For-Profit Status of Training Institution } \\
\hline Training Offer & $\begin{array}{c}0.056 * * \\
(0.027)\end{array}$ & $\begin{array}{c}33,186 * * * \\
(11,223)\end{array}$ & $\begin{array}{l}0.041^{*} \\
(0.024)\end{array}$ & $\begin{array}{c}22,036^{* *} \\
(10,487)\end{array}$ & $\begin{array}{c}0.008 \\
(0.028)\end{array}$ & $\begin{array}{c}16,534 \\
(13,613)\end{array}$ & $\begin{array}{c}0.059 * * \\
(0.030)\end{array}$ & $\begin{array}{c}38,780^{* * *} \\
(14,508)\end{array}$ \\
\hline $\begin{array}{l}\text { Training Offer } \times \\
\text { For-Profit Dummy }\end{array}$ & $\begin{array}{l}-0.012 \\
(0.047)\end{array}$ & $\begin{array}{c}-8,556 \\
(18,889)\end{array}$ & $\begin{array}{l}-0.036 \\
(0.042)\end{array}$ & $\begin{array}{c}14,731 \\
(17,906)\end{array}$ & $\begin{array}{l}0.086^{*} \\
(0.050)\end{array}$ & $\begin{array}{c}18,887 \\
(24,648)\end{array}$ & $\begin{array}{l}-0.039 \\
(0.054)\end{array}$ & $\begin{array}{l}-28,470 \\
(25,640)\end{array}$ \\
\hline $\mathrm{N}$ & 1,917 & 1,917 & 1,915 & 1,917 & 1,618 & 1,618 & 1,618 & 1,618 \\
\hline
\end{tabular}

Notes: The table reports the coefficient of the training offer dummy interacted with hours of instruction in the training institution and with a dummy that takes the value of 1 if the training institution is for profit and zero if the training institution is a non-profit organization in Panel A and Panel B for separate regressions of labor market outcomes for women and men. Robust standard errors are reported in parenthesis. All regressions control for training institution fixed effects and for pre-training age, headship status dummy, marital dummy, education, and city effects. * indicates significance at the $10 \%$ level, ${ }^{* *}$ indicates significance at the $5 \%$ level, and $* * *$ indicates significance at the $1 \%$ level. 
Table 10: Effects of Quality of Classroom Training on Overall and Formal Employment and Earnings of Women and Men

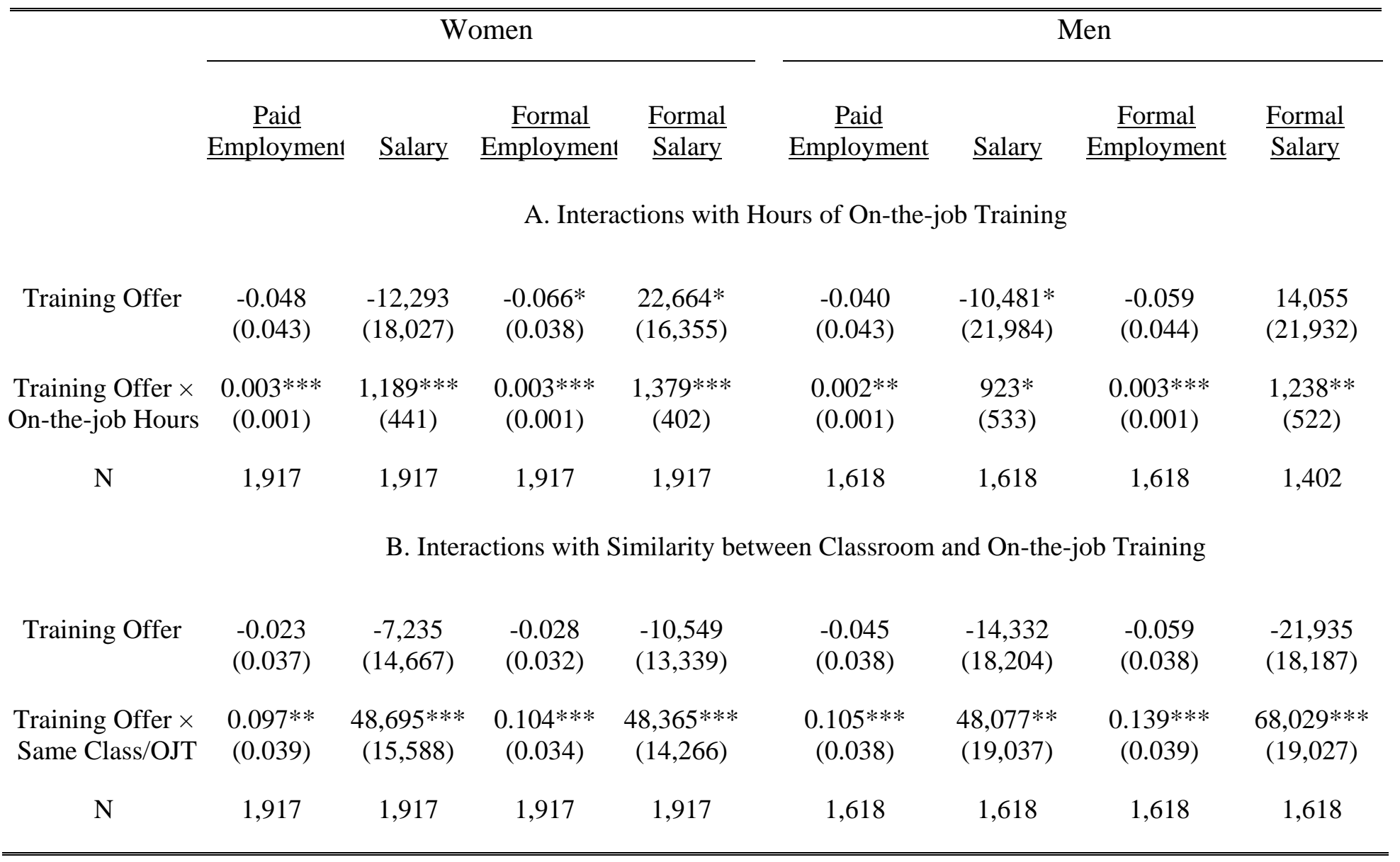

Notes: The table reports the coefficient of the training offer dummy and on the training offer dummy interacted with hours of on-the-job training in Panel A and with a dummy that takes the value of 1 if the type of training provided in the classroom and on-the-job training was in the same area in Panel B for separate regressions of labor market outcomes for women and men. Robust standard errors are reported in parenthesis. All regressions control for training institution fixed effects and for pre-training age, headship status dummy, marital dummy, education, and city effects. * indicates significance at the $10 \%$ level, ** indicates significance at the $5 \%$ level, and $* * *$ indicates significance at the $1 \%$ level. 